Diabetologia 11, 419-425 (1975)

(C) by Springer-Verlag 1975

\title{
A Combined Radioimmunoassay for Glucagon and Insulin
}

\author{
V. Leclercq-Meyer, J. Marchand, O. Rebolledo, W. J. Malaisse and R. Leclercq \\ Lab. of Experimental Medicine, Université Libre de Bruxelles and Dept. of Radioimmunology, Lab. of Clinical Pathology, Edith Cavell \\ Institute, Brussels, Belgium
}

Received: March 27, 1975, and in revised form: June 9, 1975

\begin{abstract}
Summary. A combined radioimmunoassay for glucagon and insulin in biological fluids is presented. It is based on the use of ${ }^{131} \mathrm{I}$-glucagon and ${ }^{125} \mathrm{I}$-insulin tracers and a charcoal-dextran separation procedure. Standard curves, sample determinations and recovery studies gave comparable results whether in the combined or individual assay for glucagon and insulin. The combined assay, especially if supported by a decoding and calculating computer
\end{abstract}

program, offers the advantages that it requires a smaller volume of the material to be sampled, is more economical and less timeconsuming.

Key words: Combined radioimmunoassay glucagon, insulin, perfusion media, human plasma, computer program.
It is increasingly recognized that, in the moment to moment regulation of nutrient homeostasis, fluctuations in the molar ratio of insulin to glucagon $(I / G)$ in plasma may bear greater significance than the variations of either hormone taken separately [14]. It would thus seem desirable that the concentration of both hormones can be routinely and simultaneously assessed. Furthermore, in studies dealing with the control of glucagon secretion, the knowledge of the concomitant and much better documented variations in insulin release may be helpful in assessing the validity of the experimental preparation or design used to evaluate the secretory responsiveness of the Acell.

Many investigators are currently reporting on the concomitant changes in glucagon and insulin concentrations; in most cases, each hormone is assayed separately. Only few reports mention the feasibility of combined immunoassays for protein hormones and most of them are concerned with the simultaneous assay of insulin and growth hormone $[4,10]$. To our knowledge, there is only one report devoted to the simultaneous assay of glucagon and insulin in serum [18]; with this technique, glucagon levels in human serum ranged between 5 and $60 \mathrm{ng} / \mathrm{ml}$, far above the range of values presently reported in the literature.

The present report describes a combined radioimmunoassay for glucagon and insulin. The assay is based on the utilization of ${ }^{131} \mathrm{I}$-glucagon and ${ }^{125} \mathrm{I}$-insulin as tracers and on a charcoal-dextran separation procedure. Its validity for the estimation of glucagon and insulin in either pancreatic perfusion media or human plasma samples was evaluated by comparing the results obtained with the combined assay to those of the individual assay for each hormone. In addition, we describe a computer program, devised on a programmable desk calculator, which allows for the conversion of the radioactive data into standard curves and hormone concentrations.

\section{Materials and Methods}

\section{Buffers and Solutions}

The diluent consists of a veronal buffer (20.6 g barbital sodium and $3.68 \mathrm{~g}$ barbital in 11 of distilled water, $\mathrm{pH} 8.6$ ) containing $5 \mathrm{mg} / \mathrm{ml}$ of bovine albumin (fraction V, Sigma, St. Louis, USA).

The dextran-coated charcoal suspension was prepared according to Herbert et al. [5]. It contains $12.5 \mathrm{mg} / \mathrm{ml}$ of charcoal (Norit A, Fisher, USA) and $2.5 \mathrm{mg} / \mathrm{ml}$ of dextran (T70, Pharmacia, Sweden).

Trasylol, a proteinase inhibitor was generously supplied in a powdered form by Drs. G. Schnells and G. Wald (Bayer, Wuppertal-Elberfeld, Western Germany and Bayer-Pharma, Brussels, Belgium).

\section{Glucagon and Insulin Standards}

Purified beef-pork glucagon (Lot $\mathrm{n}^{\circ}$ 258234-B-161-1) was kindly donated by Dr. M. A. Root (Ely Lilly Co., Indianapolis, USA). The insulin content of this preparation is in the range of 5.5 to 12 $\mathrm{mU} / \mathrm{mg}$. 
Crystalline rat insulin (Lot R.170, with a mean biological potency of $21.4 \mathrm{I} . \mathrm{U} . / \mathrm{mg}$ ) and crystalline human insulin (lot 27-3264) were obtained through the courtesy of Dr. J. Schlichtkrull (Novo, Bagsvaerd, Denmark).

Stock solutions of glucagon $(100 \mathrm{ng} / \mathrm{ml})$ were made up in Trasylol-containing diluent $(1000 \mathrm{KIU} / \mathrm{ml})$. Those of insulin $(10 \mathrm{mU} / \mathrm{ml})$ were made up in diluent. All were kept at $-25^{\circ} \mathrm{C}$ and thawed only once at the time of the assay where they were diluted with the Trasylol-containing diluent.

\section{Labelled Glucagon and Insulin}

${ }^{131} I$-glucagon (porcine, Novo), with specific activities ranging between 610 and $710 \mu \mathrm{Ci} / \mu \mathrm{g}$, was purchased from the Centre National de Transfusion Sanguine (Paris, France).

${ }^{125}$ I-insulin (bovine) with specific activities ranging between 100 and $200 \mu \mathrm{Ci} / \mu \mathrm{g}$, was obtained from SORIN (Saluggia, Italy).

The labelled hormones were kept at $-25^{\circ} \mathrm{C}$ and thawed only once at the time of the assay. Both were utilized without further purification.

\section{Glucagon and Insulin Antisera}

The anti-glucagon serum (AGS) was obtained in this laboratory, as described elsewhere [7]. Guineapig anti-insulin serum (GPAIS) was a gift from Dr. P. H. Wright (Indiana University, Indianapolis, USA).

\section{Incubation and Separation Procedures}

Table 1 illustrates the design of the incubation and separation procedures of the combined assay applied to perfusion media and human plasma. The individual assays for glucagon or insulin were performed according to the same schemes, except of course that in the glucagon assay, the reagents belonging to the insulin assay (insulin standards, GPAIS and ${ }^{125}$ I-insulin) were omitted, and vice versa.

In all the assays, the reagents were added in the same order: first, the standards and the unknown samples, second, the antisera, and third, the tracers. In the combined assays, the standards, the antisera and the tracers were mixed beforehand. The tracers, diluted with diluent and Trasylol in order to bring the concentration of Trasylol to $1000 \mathrm{KIU}$ per tube after pipett-

Table 1. Experimental design of the combined assay for glucagon and insulin in incubation media and human plasma. Mo $=$ perfusion media containing no glucagon and no insulin; AGS = anti-glucagon serum; GPAIS = guinea-pig anti-insulin serum; f.d. final dilution. The amount of $30 \mathrm{pg}{ }^{131} \mathrm{I}$-glucagon represents the mean amount of tracer being added; it varied $(25 \mathrm{fo} 50 \mathrm{pg})$ according to the number of tubes to be assayed

\begin{tabular}{|c|c|c|c|c|c|c|c|c|c|c|c|c|}
\hline \multirow[b]{2}{*}{$\begin{array}{l}\text { Type } \\
\text { of } \\
\text { assay }\end{array}$} & \multicolumn{10}{|c|}{ Incubation procedure } & \multicolumn{2}{|c|}{ Separation } \\
\hline & $\begin{array}{l}\text { Unlabelled } \\
\text { glucagon } \\
\text { pg }\end{array}$ & $\begin{array}{l}\text { insulin } \\
\mu \mathrm{U}\end{array}$ & $\begin{array}{l}\mathrm{N}^{\mathrm{o}} \text { of } \\
\text { Tubes }\end{array}$ & $\begin{array}{l}\text { Unknown } \\
\text { samples }\end{array}$ & AGS & AIS & $\begin{array}{l}{ }^{131} \mathrm{I}- \\
\text { glucagon } \\
\mathrm{pg}\end{array}$ & $\begin{array}{l}{ }^{125} \mathrm{I}- \\
\text { insulin }\end{array}$ & Trasylol & $\begin{array}{l}\text { Total } \\
\text { volume in } \\
\text { diluent } \\
\mathrm{ml}\end{array}$ & $\begin{array}{l}\begin{array}{l}\text { Beef } \\
\text { serum }\end{array} \\
\mathrm{mI}\end{array}$ & $\begin{array}{l}\text { charcoal- } \\
\text { dextran } \\
\mathrm{ml}\end{array}$ \\
\hline & standard blank & & 3 & $0.2(\mathrm{Mo})$ & - & - & $\sim 30$ & 85 & 1000 & 0.9 & 0.20 & 2 \\
\hline combined & 0 & 0 & 3 & $0.2(\mathrm{Mo})$ & $1: 19,800$ & $1: 180,000$ & $"$ & $"$ & " & $"$ & 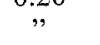 & $"$ \\
\hline assay & 20 & 1 & 2 & $0.2(\mathrm{Mo})$ & $"$ & $"$ & $"$ & $"$ & $"$ & $"$ & $"$ & \\
\hline & to & to & & & & & & & & & & \\
\hline perfusion & 1000 & 50 & 2 & $0.2(\mathrm{Mo})$ & $"$ & $"$ & $"$ & $"$ & $"$ & $"$ & $"$ & $"$ \\
\hline media & unknown blank & & 2 & 0.2 & - & - & $"$ & $"$ & $"$ & $"$ & $"$ & $"$ \\
\hline $\begin{array}{l}\text { (rat } \\
\text { insulin }\end{array}$ & $\begin{array}{l}\mathbf{x}_{1} \\
\text { to }\end{array}$ & & 2 & 0.2 & $1: 19,800$ & $1: 180,000$ & $0 "$ & $"$ & $"$ & $"$ & $"$ & $"$ \\
\hline $\begin{array}{l}\text { insulin } \\
\text { as }\end{array}$ & $\begin{array}{l}\text { to } \\
\mathrm{x}_{10}\end{array}$ & & 2 & 0.2 & ", & $"$ & $"$ & $"$ & ," & ", & $"$ & $"$ \\
\hline standard) & unknown blank & & 2 & 0.2 & - & - & $"$ & $"$ & $"$ & " & $"$ & $"$ \\
\hline & standard blank & & 3 & - & - & - & $\sim 30$ & 85 & 1000 & 0.9 & 0.20 & 2 \\
\hline combined & 0 & 0 & 3 & - & $1: 19,800$ & $1: 180,000$ & $9 "$ & $"$ & $"$ & $"$ & $"$ & $"$ \\
\hline assay & 20 & 1 & 2 & - & ," & $"$ & " & ", & , & $"$ & $"$ & $"$ \\
\hline in human & to & to & & & & & & & & & & \\
\hline plasma & 1000 & 50 & 2 & - & $"$ & $"$ & $"$ & $"$ & $"$ & $"$ & $"$ & $"$ \\
\hline (human & unknown blank & & 2 & 0.2 & - & - & $"$ & $"$ & $"$ & $"$ & - & $"$ \\
\hline insulin & $\mathrm{x}_{1}$ & & 2 & 0.2 & $1: 19,800$ & $1: 180,000$ & $0 "$ & $"$ & $"$ & $"$ & - & $"$ \\
\hline as & to & & & & & & & & & & & \\
\hline standard) & $\mathbf{x}_{10}$ & & 2 & 0.2 & $"$ & $"$ & $"$ & $"$ & $"$ & $"$ & - & $"$ \\
\hline & $\begin{array}{l}\mathrm{A}_{10} \\
\text { unknown blank }\end{array}$ & & 2 & 0.2 & - & - & ", & $"$ & ", & $"$ & - & $"$ \\
\hline
\end{tabular}


ing, were always introduced into the tubes at least one hour after the antisera. At the beginning of these studies, all the pipetting was performed manually, but, except for the standard curves which are still pipetted by hand, all the other reagents are now added using semiautomatic diluting instruments (Digistrib and Digitil, Gilson, Villers-le-Bel, France).

The incubation was in disposable $5 \mathrm{ml}$ plastic tubes for 3 days with constant shaking. At the end of the incubation period, beef serum and charcoal-dextran were added, the charcoal-dextran suspension being distributed by means of an automatic $5 \mathrm{ml}$ Cornwall syringe. The assay tubes were then allowed to stand for $20 \mathrm{~min}$ and centrifuged at $2600 \mathrm{RPM}$ for $25 \mathrm{~min}$.

During all the foregoing procedures the tubes were maintained at $4^{\circ} \mathrm{C}$. Immediately after centrifugation, the supernatant was decanted and the tubes dried upside down at $60^{\circ} \mathrm{C}$.

\section{Counting and Calculations}

The tubes containing the charcoal fraction were counted for $4 \mathrm{~min}$ in an autogamma spectrometer with dual channels (Philips). The two channels were ad-

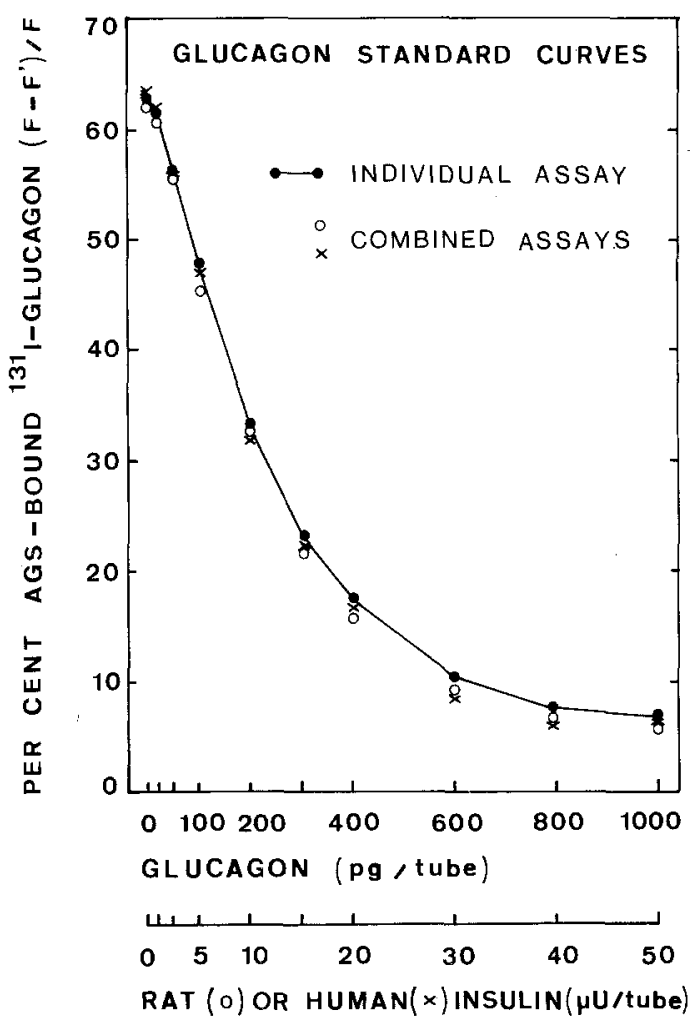

Fig. 1. Glucagon standard curves obtained in the individual assay for glucagon and the combined assays for glucagon and insulin, all performed in one assay run. The zero points were from triplicate and all the others from duplicate determinations. Individual determinations did not differ from each other by more than 1 per cent justed at the major energy peaks for ${ }^{131} \mathrm{I}$ and ${ }^{125} \mathrm{I}$ respectively. Under these conditions, ${ }^{125} \mathrm{I}$ emissions were not detected in the ${ }^{131} \mathrm{I}$ channel, but about 10 per cent of the radioactivity detected in the ${ }^{131}$ I channel was detected in the ${ }^{125} \mathrm{I}$ channel. Thus, appropriate correction was performed in order to obtain the net ${ }^{125}$ I counts.

The per cent of antibody-bound ${ }^{131}$ I-glucagon and ${ }^{125}$ I-insulin (Fig. 1 to 3 ) was determined as outlined in detail in previous work (7), using the following formula

in which

$$
\left[\left(\mathrm{F}-\mathrm{F}^{\prime}\right) / \mathrm{F}\right] \times 100
$$

$\mathrm{F}=$ charcoal-adsorbed radioactivity in the blanks without antisera (standard blanks, unknown blanks)

$\mathrm{F}^{\prime}=$ charcoal-adsorbed radioactivity in the tubes containing antisera (standards, unknown samples).

In order to circumvent the problem of the decay of ${ }^{131} \mathrm{I}$, unknown blanks were introduced in the assay at regular intervals. Thus, the mean $\mathrm{F}$ value obtained from the 3 standard blanks (Table 1) was used to calculate the per cent of binding at all points of the standard curves. The per cent of binding in the presence of unknown samples was calculated using a new $F$ value for each set of 10 samples (or every 20 tubes). This $\mathrm{F}$ value represented the mean of 4 unknown blanks, 2 being placed in front and 2 at the back of these samples ( $\mathrm{x}_{1}$ to $\mathrm{x}_{10}$, Table 1$)$.

\section{Computer Program}

The computer program was devised using a pregrammable desk calculator (Wang 600-14-T.P., capacity : $1.8 \mathrm{k}$ words of 8 bits, Wang, Tewksbury, Mass., USA). Two forms were developed, one of which could be applied to the combined assay and the other to a separate assay. Both forms were constructed on the basis of a point to point linearisation of our standard curves (see Figs. 1 to 3 ).

The program for the combined assay essentially included the following steps: a) correction of the ${ }^{125} \mathrm{I}$ counts from the overlapping of the ${ }^{131} \mathrm{I}$ counts in the ${ }^{125}$ I channel; b) correction of the ${ }^{131} I$ and ${ }^{125} I$ counts by the respective background counts; c) calculation of the mean per cent binding at each concentration in the respective standard curves for glucagon and insulin; d) computation of the slope and ordinate at the origin for each of the successive linear segments of the two standard curves; e) calculation of the per cent of binding in unknown samples and conversion into glucagon and insulin concentrations. 


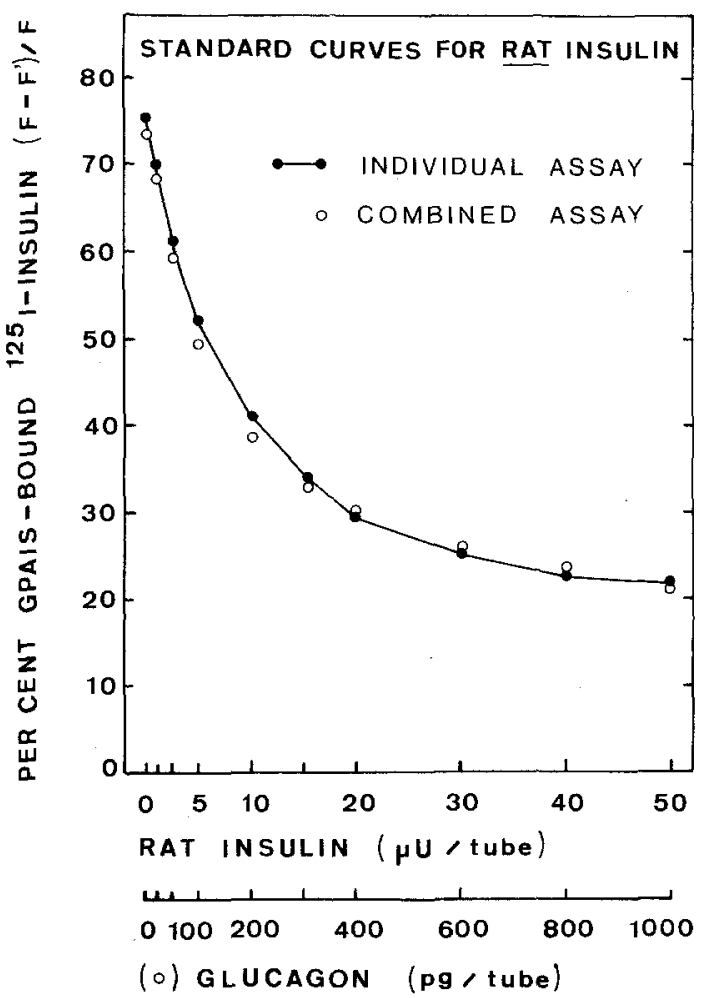

Fig. 2. Standard curves for rat insulin obtained in the individual assay and the combined assay. Number of determinations at each point as for Fig. 1

The program for the individual assays was constructed according to the same scheme except for the omission of step a.

\section{Results}

\section{Standard Curves}

The glucagon standard curves were comparable, whether obtained in the individual or combined assays (fig. 1). Thus, in our assay system, the glucagon-AGS binding reaction is unaffected by the presence of ${ }^{125} \mathrm{I}$ insulin, GPAIS, and unlabelled rat or human insulin added in concentrations up to $50 \mu \mathrm{U}$ per tube.

Similarly, the insulin standard curves, performed with either unlabelled rat (Fig. 2) or human insulin (Fig. 3), did not significantly differ whether obtained in the individual or combined assays. This indicates that the insulin-GPAIS reaction is similarly unaffected by the reagents of the other assay system, in the presence of unlabelled glucagon added in concentrations up to $1000 \mathrm{pg}$ per tube.

\section{Glucagon and Insulin Determinations in Unknown Samples}

a) In Perfusion Media, Using Rat Insulin as Standard. The perfusion medium consisted of a Krebs Ringer bicarbonate buffer containing 4 per cent bovine albumin (Fraction V, Pentex, Miles-Severac, Maidenhead, Berkshire, England; or Sigma, St. Louis, USA), and which had been circulated through the rat pancreas $[8,12]$. The estimation of glucagon and insulin in such media yielded closely similar values using the individual and the combined assays. Thus, Fig. 4 illustrates the secretory response, assessed by both assay systems, of a perfused rat pancreas exposed to changing glucose concentrations. Furthermore, regression analysis revealed highly significant correlations between the values obtained in the individual and the combined assay for both glucagon $(\mathrm{r}$ $=0.996, \mathrm{P}<0.001, \mathrm{n}=85)$ and insulin $(\mathrm{r}=0.984, \mathrm{P}$ $<0.001, \mathrm{n}=79$ ). In addition, the slope of the calculated regression lines did not differ significantly from unity (line of identity).

b) In Human Plasma, Using Human Insulin as Standard. Glucagon and insulin determinations were carried out in random human heparinized plasma samples. These samples were not collected on Trasylol, but we had observed previously that the estimation of glucagon in human plasma yielded similar values irrespective of the addition of Trasylol at the time of collection [7]. Regression analysis also indicated for human plasma a highly significant correlation for glucagon-like immunoreactivity (GLI) . $(\mathrm{r}=0.873, \mathrm{P}<0.001, \mathrm{n}=72)$ as well as for insulin ( $\mathrm{r}=0.989, \mathrm{P}<0.001, \mathrm{n}=50)$ and, as in the case of the perfusion media, the slope of the calculated regression lines did not differ significantly from unity.

\section{Recovery Studies}

a) In Perfusion Media. Increasing amounts of unlabelled beef-pork glucagon and rat insulin were added to a perfusion medium containing $1000 \mathrm{KIU}$ Trasylol per $\mathrm{ml}$ but which had not been circulated through the pancreas. The mean per cent recovery ( \pm SEM) of glucagon in the individual assay was not statistically different from that observed in the combined assay $(98.4 \pm 1.8$ versus $104.4 \pm 2.9, \mathrm{P}>0.10)$. Similarly, the mean per cent recovery of insulin was comparable in the individual and combined assays $(98.6 \pm 2.7$ versus $98.7 \pm 3.8, \mathrm{P}>0.10)$.

b) In Human Plasma (Table 2). Unlabelled beefpork glucagon and human insulin were added to human plasma in the presence of $1000 \mathrm{KIU}$ Trasylol per $\mathrm{ml}$. The recovery studies were performed on 2 to 3 


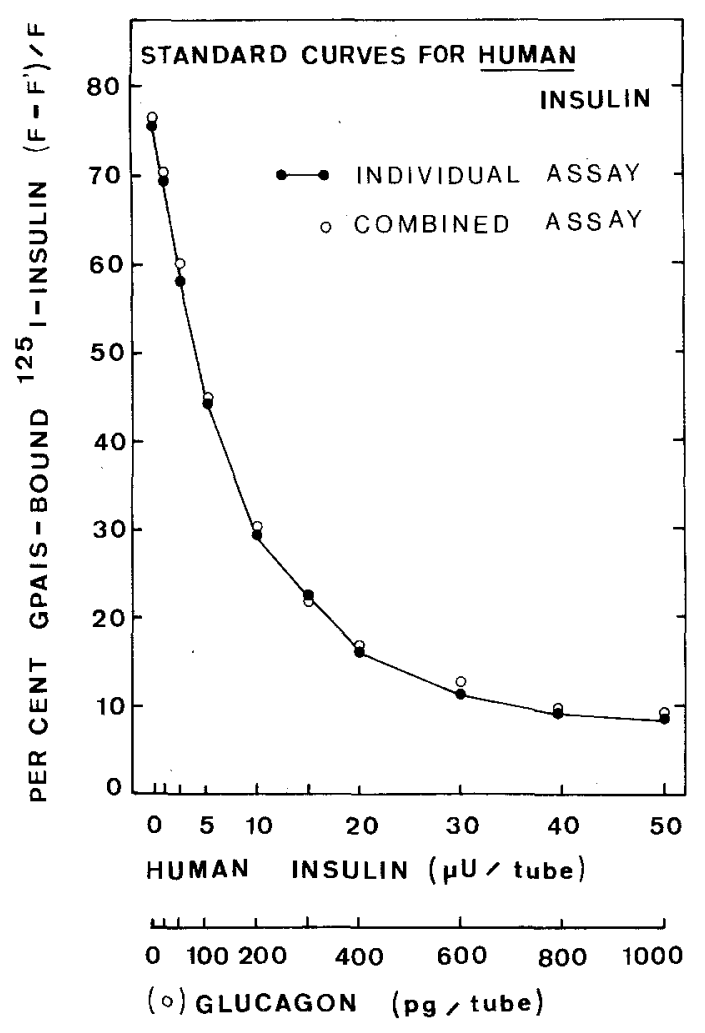

Fig. 3. Standard curves for human insulin obtained in the individual assay and the combined assay. Number of determinations at each point as for Fig. 1

occasions. The mean per cent recoveries of glucagon in human plasma were about 10 per cent lower than those observed in the perfusion media. However, they were comparable using the individual and the combined assays $(88.1 \pm 2.7$ versus $87.8 \pm 1.2, \mathrm{P}>$ $0.10)$. Incidentally, these values are of the same order as those reported previously over 7 consecutive trials using our individual glucagon assay [7]. On the other hand, the mean per cent recovery of insulin averaged 100 per cent and was similar in both assay systems $(102.8 \pm 1.9$ versus $100.1 \pm 2.1, \mathrm{P}>0.10)$.

\section{Discussion}

All the foregoing data indicate that it is possible to assay glucagon and insulin simultaneously, in both perfusion media and human plasma samples, using ${ }^{131}$ I-glucagon and ${ }^{125} \mathrm{I}$-insulin as tracers. This possibility is strongly supported by the fact that all of the studied parameters (standard curves, hormonal determinations in unknown samples, recovery studies) were comparable whether using the individual assays for each hormone or the combined assays.

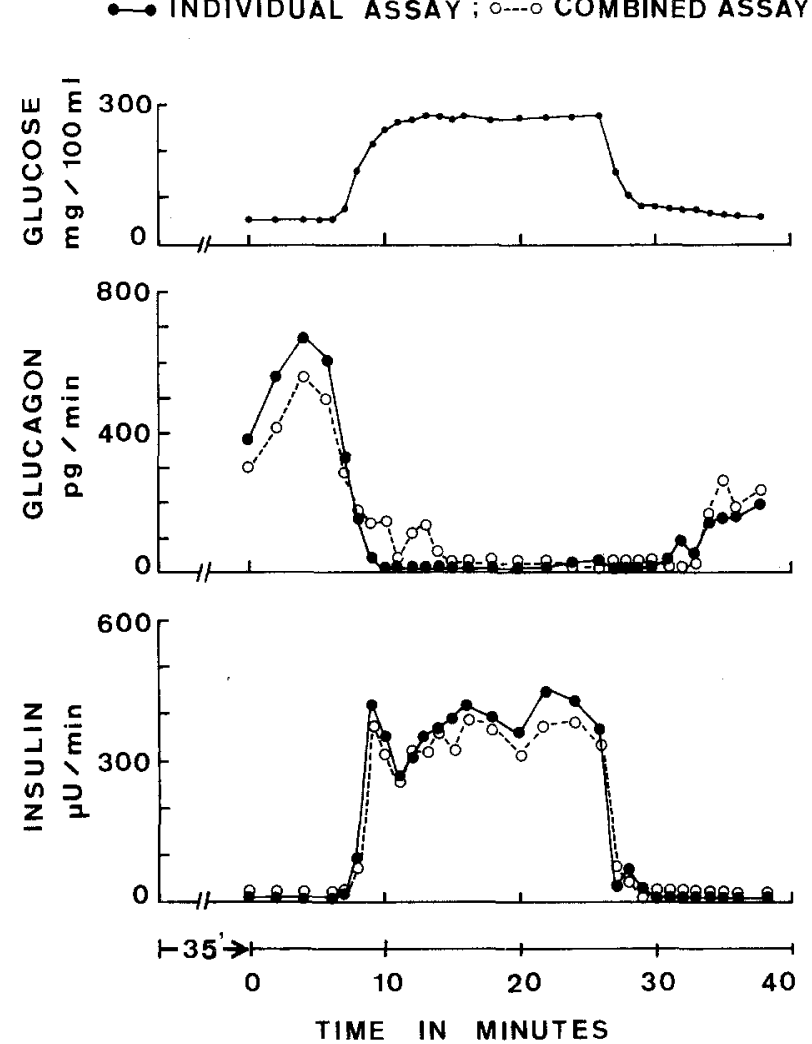

Fig. 4. Glucagon and insulin release from a perfused rat pancreas in response to changing glucose concentrations $(3.3$ to $16.6 \mathrm{mM}$ and back), as measured with the individual assays for each hormone or the combined assay. The measurements were initiated at time 0 , following a $35 \mathrm{~min}$ equilibration period. The flow of that particular experiment having been $1.8 \mathrm{ml} / \mathrm{min}$, and the effluent collected in $0.1 \mathrm{ml}$ Trasylol (1000 KIU), the reported hormonal output values are the result of a multiplication by a factor of 9.5 . Glucose was measured in the pancreatic effluent by a ferricyanide method using a Technicon Auto Analyser

The utilization of a combined assay in place of individual assays presents many advantages. Thus, it is more economical, is less time-consuming and requires smaller amounts of unknown samples. Furthermore, it can meet the requirements of many forthcoming experimental and clinical investigations, since it is increasingly evident that the A and the B-cells of the pancreas should be looked upon as a bihormonal unit controlling the moment to moment nutrient homeostasis in both physiological and pathological states, including diabetes $[1,2,9,11,15,16,17]$.

The establishment of the combined assay presents no difficulty, provided that a gamma counter with two channels is available. However, each laboratory will probably have to assess its ability to perform its own combined assay. And, in particular, it would have to be checked that such an assay is feasible with separa- 
Table 2. Recovery of unlabelled beef-pork glucagon and human insulin added to human plasma using the individual or combined assay. The number of assays performed (n) and the standard error of the mean (SEM) are indicated. In each assay, the glucagon and insulin values represented the mean of duplicate or triplicate determinations

\begin{tabular}{|c|c|c|c|c|}
\hline \multirow{3}{*}{$\begin{array}{l}\text { Added } \\
\text { glucagon } \\
\mathrm{pg} / \mathrm{ml}\end{array}$} & \multicolumn{4}{|c|}{ Recovery of added glucagon } \\
\hline & \multicolumn{2}{|c|}{ individual assay $(\mathrm{n}=2)$} & \multicolumn{2}{|c|}{ combined assay $(n=3)$} \\
\hline & $\mathrm{pg} / \mathrm{ml} \pm \mathrm{SEM}$ & $(\% \pm \mathrm{SEM})$ & $\mathrm{pg} / \mathrm{ml} \pm \mathrm{SEM}$ & $(\% \pm \mathrm{SEM})$ \\
\hline 250 & $237 \pm 24$ & $(95.0 \pm 9.8)$ & $225 \pm 18$ & $(89.9 \pm 7.3)$ \\
\hline 500 & $396 \pm 6$ & $(79.2 \pm 1.3)$ & $429 \pm 26$ & $(85.9 \pm 5.4)$ \\
\hline 1000 & $894 \pm 39$ & $(89.4 \pm 3.9)$ & $866 \pm 12$ & $(86.6 \pm 1.2)$ \\
\hline 2000 & $1831 \pm 58$ & $(91.4 \pm 2.8)$ & $1823 \pm 74$ & $(91.2 \pm 3.7)$ \\
\hline 4000 & $3430 \pm 525$ & $(85.7 \pm 13.1)$ & $3411 \pm 16$ & $(85.3 \pm 7.9)$ \\
\hline \multicolumn{2}{|c|}{ Mean recovery $\pm \operatorname{SEM}(n=5)$} & $(88.1 \pm 2.7)$ & & $(87.8 \pm 1.2)$ \\
\hline \multirow{2}{*}{$\begin{array}{l}\text { Added } \\
\text { insulin }\end{array}$} & \multicolumn{4}{|c|}{ Recovery of added insulin } \\
\hline & \multicolumn{2}{|c|}{ individual assay $(\mathrm{n}=2)$} & \multicolumn{2}{|c|}{ combined assay $(\mathrm{n}=3)$} \\
\hline$\mu \mathrm{U} / \mathrm{ml}$ & $\mu \mathrm{U} / \mathrm{ml} \pm \mathrm{SEM}$ & $(\% \pm \mathrm{SEM})$ & $\mu \mathrm{U} / \mathrm{ml} \pm \mathrm{SEM}$ & $(\% \pm \mathrm{SEM})$ \\
\hline 12.5 & $11.9 \pm 0$ & $(95.2 \pm 0)$ & $11.8 \pm 0.9$ & $(94.1 \pm 7.1)$ \\
\hline 25.0 & $25.8 \pm 1.0$ & $(103.4 \pm 4.2)$ & $24.1 \pm 1.2$ & $(96.3 \pm 4.9)$ \\
\hline 50.0 & $52.6 \pm 4.5$ & $(105.2 \pm 8.3)$ & $50.8 \pm 4.7$ & $(101.6 \pm 2.2)$ \\
\hline 100.0 & $104.7 \pm 7.4$ & $(104.7 \pm 7.4)$ & $103.8 \pm 7.8$ & $(103.8 \pm 7.8)$ \\
\hline 200.0 & $211.5 \pm 3.7$ & $(105.7 \pm 1.9)$ & $209.1 \pm 27.1$ & $(104.5 \pm 13.5)$ \\
\hline \multicolumn{2}{|c|}{ Mean recovery $\pm \operatorname{SEM}(n=5)$} & $(102.8 \pm 1.9)$ & & $(100.1 \pm 2.1)$ \\
\hline
\end{tabular}

tion procedures other than charcoaldextran, and, perhaps more important, that the binding of one of the hormones to its particular antibody is not altered by the presence of the reagents (antibody, tracer, or standards) used in the assay of the other.

Although the processing of the radioactive data into hormonal concentrations can be done manually, even in the combined assay, the availability of a computer program is of considerable practical interest in that it further alleviates the time-consuming procedures involved in the analysis of any radioimmunoassay.

Although numerous mathematical expressions, usually tending to a linearisation of the whole standard curve, are available for curve-fitting and automatic treatment of the assay results [13], we adopted a point to point linearisation of our standard curves. This procedure has the advantage of always matching the experimental results over the whole range of the standard points, which might not always be the case for other curve-fitting models [3].

Acknowledgements. This work was supported in part by grants 20.001 and 20.193 from the FRSM, FNRS, and a contract of the Ministère de la Politique Scientifique (Belgium) within the framework of the association Euratom-Universities of Brussels and Pisa. The authors wish to thank Dr. H.A. Ooms (Laboratory of Clinical Chemistry, Hôpital Saint-Pierre, Brussels, Belgium) for having made ${ }^{125} \mathrm{I}$-insulin and the human insulin standard available to us. They also are grateful to Mrs. B. Noël for secretarial help. O.E. Rebolledo was supported by a fellowship from the Consejo Nacional de Investigaciones Cientificas y Técnicas de la República Argentina.

\section{References}

1. Cherrington, A.D., Vranic, M.: Effect of interaction between insulin and glucagon on glucose turnover and FFA concentration in normal and depancreatized dogs. Metabolism 23, 729-744 (1974)

2. Dobbs, R., Sakurai, H., Sasaki, H., Faloona, G., Valverde, I., Baetens, D., Orci, L., Unger, R.H.: Glucagon's role in the hyperglycemia of diabetes mellitus. Science 187, 544-547 (1975)

3. Ekins, R.P.: Radioimmunoassay and saturation analysis. Basic principles and theory. Brit. med. Bull. 30, 3-11 (1974)

4. Glick, S.M., Kagan, A.: Combined immunoassay of insulin and human growth hormone. J. clin. Endocr. 27, 133-136 (1967)

5. Herbert, V., Lau, K.S., Gottlieb, C. W., Bleicher, S. J.: Coated charcoal immunoassay of insulin. J. clin. Endocr. 25, 1375-1384 (1965)

6. Leclercq-Meyer, V., Marchand, J., Malaisse, W.J.: Possible role of a microtubular-microfilamentous system in glucagon secretion. Diabetologia 10, 215-224 (1974) 
7. Leclercq-Meyer, V., Mialhe, P., Malaisse, W.J.: Une méthode de dosage radioimmunologique du glucagon comportant une séparation par le charbon-dextran. Diabetologia 6, 121-129 (1970)

8. Leclercq-Meyer, V., Rebolledo, O., Marchand, J., Malaisse, W.J.: Glucagon release: paradoxical stimulation by glucose during calcium deprivation. Science, (in press) (1975)

9. Liljenquist, J.E., Bomboy, J.D., Lewis, S.B., Sinclair-Smith, B.C., Felts, P. W., Lacy, W. W., Crofford, O. B., Liddle, G. W.: Effects of glucagon on lipolysis and ketogenesis in normal and diabetic Men. J. clin. Invest. 53, 190-197 (1974)

10. Morgan, C.R.: Immunoassay of human insulin and growth hormone simultaneously using I-131 and I-125 tracers. Proc. Soc. exp. Biol. (N.Y.) 123, 230-233 (1966)

11. Parrilla, R., Goodman, M.N., Toews, C.J.: Effect of glucagon: insulin ratios on hepatic metabolism. Diabetes 23, 725-731 (1974)

12. Rebolledo, O., Leclercq-Meyer, V., Marchand, J., Malaisse, W.J.: Failure of parathormone to affect insulinı and glucagon release from the perfused rat pancreas. Horm. Metab. Res. 7, 287-290 (1975)

13. Rodbard, D.: Statistical quality control and routine data proces- sing for radioimmunoassays and immunoradiometric assays. Clin. Chem. 20, 1255-1270 (1974)

14. Unger, R.H.: Glucagon and the insulin: glucagon ratio in diabetes and other catabolic illnesses. Diabetes 20, 834-838 (1971)

15. Unger, R.H.: Alpha- and beta-cell interrelationships in health and disease. Metabolism 23, 581-593 (1974)

16. Unger, R.H., Lefebvre, P.J.: Glucagon physiology. In: Glucagon, molecular physiology, clinical and therapeutic implications (eds. P.J. Lefebvre, R.H. Unger) pp. 213-244. Oxford: Pergamon Press 1972

17. Unger, R.H., Orci, L.: The essential role of glucagon in the pathogenesis of diabetes mellitus. Lancet 1975 I, 14-16

18. Young, J.D., Kraegen, E. W.: Simultaneous assay of insulin and glucagon in serum. Aust. J. exp. Biol. med. Sci. 46, 697-705 (1968)

Dr. V. Leclercq-Meyer

Laboratoire de Médecine

Expérimentale

Bld. de Waterloo 115

B-1000 Bruxelles

Belgium 